\title{
Episomal detection of Banana streak OL virus in single and mixed infection with Cucumber mosaic virus in banana 'Nanicão Jangada'
}

\author{
Patrícia R. Carnelossi ${ }^{1}$, Taise Bijora ${ }^{1}$, Cassiele U. Facco ${ }^{1}$, Jaqueline M. Silva1, Marcelo H. S. Picoli ${ }^{1}$, Eliezer \\ R. Souto ${ }^{1} \&$ Fernando T. de Oliveira ${ }^{2}$
}

'Departamento de Agronomia, Universidade Estadual de Maringá, Maringá, PR, 87020-900, Brazil; ${ }^{2}$ Instituto Paranaense de Assistência Técnica e Extensão Rural, Andirá, PR, 86380-000, Brazil

Author for correspondence: Eliezer R. Souto, e-mail: ersouto@uem.br

\begin{abstract}
Banana streak virus (BSV) and Cucumber mosaic virus (CMV) are commonly found in all banana growing-areas of the world. These viruses cause diseases that lead to yield reduction and constrain plant breeding and distribution of Musa germplasm. Most of the diagnostic methods targeting BSV can generate dubious results because of the considerable genetic and serological diversity among BSV isolates and the presence of integrated BSV sequences in the banana plant. Both viruses are usually detected in single and mixed infections in banana plantations in the north region of Paraná state using DAS-ELISA and PCR. A rolling-circle amplification protocol tested in this study allowed specific detection and identification of an episomal BSV isolate infecting Nanicão Jangada cultivar, thus confirming the occurrence of Banana streak OL virus in Brazil.
\end{abstract}

Key words: Badnavirus, Cucumovirus, Musaceae, RT-PCR, rolling-circle amplification.

World banana (Musa spp.) production in 2011 was 102 million tons, primarily from plantations in India, Brazil, Ecuador, China and the Philippines (FAO, 2012). Banana cultivars originated from two wild species, Musa acuminata Colla (A genome) and M. balbisiana Colla (B genome), resulting in a series of diploid, triploid and tetraploid genomes (AA, $\mathrm{AB}, \mathrm{AAA}, \mathrm{AAB}, \mathrm{ABB}, \mathrm{AABB}$, AAAB, ABBB) (Simmonds, 1976). The worldwide movement of banana hybrids has been affected by the difficulty in obtaining virus-free plantlets through tissue culture due to the occurrence of mosaic disease caused by CMV (Cucumber mosaic virus), family Bromoviridae, and streak disease caused by BSV (Banana streak virus). Currently, BSV is considered a major constraint to banana improvement and poses a threat to Musa production worldwide (James et al., 2011).

The most typical symptoms of BSV infection are broken or continuous streaks on the leaf lamina, which may vary from yellow, chlorotic, black or brown color. Mild symptoms include faint broken chlorotic lines or eyespots, while more severe symptoms consist of necrosis of various part of the plant, causing its death. Since BSV symptoms may be confounded with CMV symptoms, accurate diagnosis cannot rely on visual assessments (Lockhart \& Jones, 2000). BSV is a member of the genus Badnavirus in the family Caulimoviridae. Its genome comprises noncovalently closed, double-stranded DNA of approximately 7.2 to $7.8 \mathrm{kbp}$. Four BSV species are currently recognized: Banana streak Mysore virus (BSMyV), Banana streak GF virus (BSGFV), Banana streak $O L$ virus (BSOLV), and Banana streak VN virus (BSVNV) (Geering \& Hull, 2012). Nevertheless, many other species of BSV may occur based on numerous reported partial sequences (Figueiredo et al., 2006). BSV can occur in two main forms within the host, firstly integrated into the host genome (endogenous BSV) and secondly in an episomal form (episomal BSV). Episomal infection may result due to the integrated form of the virus being expressed within the plant (Ndowora \& Lockhart, 2000), or by introduction to the plant via mealybug vectors from an external source of viruses. Although incomplete integrants have been found in both A and B genomes, endogenous activatable forms of BSV have only been detected in the B genome of various banana accessions, particularly subjected to certain stress conditions, such as tissue culture (Geering et al., 2005).

A genetic mechanism of recombination may be responsible for triggering endogenous $\mathrm{BSV}$ to become episomal because of an inhibiting factor present with the homologous BB genome and absence of endogenous BSV in recombined genes such as AAB (Lheureux et al., 2003).

In northern Paraná, the cultivation of fruit crops, especially bananas, has been intensified as a profit alternative for small farmers in a typical soybean and cornproduction region. The monitoring of banana viruses is critical considering the widespread occurrence of CMV and $\mathrm{BSV}$, and the absence of effective resistance in Musa to any 
of these viruses. Hence, control strategies rely largely on the use of virus-free planting material (Brioso et al., 2000).

Leaf samples were taken from 'Nanicão Jangada' (AAA) showing leaf streaking symptoms, and from asymptomatic plants of 'Grand Naine' (AAA), 'Nanicão comum' (AAA), 'IAC 2001' (AAA), 'Maçã' and 'Prata Anã' (AAB).

Samples were tested through double-antibody sandwich (DAS)-ELISA, with a polyclonal SCBV commercial kit, and with a CMV polyclonal antiserum following manufacturer's (Agdia) instructions. Samples of lyophilized healthy banana leaves acquired from Agdia were used as negative control. Each sample was tested in triplicate wells of a polystyrene microtiter plate. Tests were considered positive when the absorbance $\left(\mathrm{A}_{405}\right)$ value of each sample was at least two times greater than that of the healthy control.

For BSV detection, plant total DNA extraction was performed according to James et al. (2011). Fresh (0.4 g) leaf tissue was ground in $3 \mathrm{~mL}$ of extraction buffer $(100$ $\mathrm{mM}$ Tris-HCl, $\mathrm{pH}$ 8.0; $50 \mathrm{mM}$ EDTA; $1.4 \mathrm{M} \mathrm{NaCl} ; 80 \mathrm{mM}$ $\mathrm{Na}_{2} \mathrm{SO}_{3} ; 2 \%$ PVP-10; and 2\% cetyltrimethylammonium bromide) using a mortar and pestle. Samples were incubated at $65^{\circ} \mathrm{C}$ for $15 \mathrm{~min}$ and then centrifuged for $5 \mathrm{~min}$ at 12,000 $\mathrm{rpm}$. The supernatant was subsequently mixed with an equal volume of chloroform: isoamylalcohol (24:1) and the mixture centrifuged at $12,000 \mathrm{rpm}$ for $5 \mathrm{~min}$. After a second chloroform extraction, the supernatant was mixed with an equal volume of isopropanol and incubated at room temperature for $5 \mathrm{~min}$. Nucleic acids were pelleted by centrifugation as described above, and pellets were washed with $70 \%$ ethanol, air dried, and resuspended in $50 \mu \mathrm{L}$ of sterile distilled water.

The extraction of plant total RNA for CMV detection was made by combining the CTAB extraction protocol (James et al., 2011), and the Trizol reagent extraction method. Banana leaves $(0,4 \mathrm{~g})$ ground in liquid nitrogen were homogenized in $3 \mathrm{~mL}$ of extraction buffer plus $2 \%$ cetyltrimethylammonium bromide and transferred to $1,5 \mathrm{~mL}$ microcentrifuge tubes. Samples were maintained at $65^{\circ} \mathrm{C}$ for $30 \mathrm{~min}$, shaken at $10 \mathrm{~min}$ intervals before adding 1 volume of Trizol reagent following manufacturer's protocol.

For BSV detection by PCR, reaction procedures were as described in Harper et al., (2002), with degenerate primers, forward $1 \mathrm{~A}$ (5'-CTNTAYGARTGGYTGT NATGCCNTTYGG), and reverse primer $4^{\prime}$ (5'TCCAYTTRCANAYNSCNCCC CANCC) to amplify a 600-bp fragment of the RT/RNaseH-coding region (ORF3). PCR cycle conditions were an initial denaturation at $94^{\circ} \mathrm{C}$ for $10 \mathrm{~min}, 5$ cycles of $94^{\circ} \mathrm{C}$ for $30 \mathrm{~s}, 37^{\circ} \mathrm{C}$ for $30 \mathrm{~s}$ and $72^{\circ} \mathrm{C}$ for $90 \mathrm{~s}$, followed by 30 cycles $\left(94^{\circ} \mathrm{C}\right.$ for $30 \mathrm{~s}, 50^{\circ} \mathrm{C}$ for $30 \mathrm{~s}$, $72^{\circ} \mathrm{C}$ for $1 \mathrm{~min}$ ) and a final extension of $72^{\circ} \mathrm{C}$ for $1 \mathrm{~min}$.

For CMV detection, RT-PCR was performed with forward primer CMV-2 (5'TATGATAAGAAGCTTGTTTCGCG), and reverse CMV-1 (5'-GCCGTAAGCTG GATGGACAA) (Wylie et al., 1993), which amplify approximately a $500 \mathrm{bp}$ fragment of the putative viral coat protein gene. For cDNA synthesis with M-MLV reverse transcriptase (Invitrogen) and reverse CMV-1 primer, total RNA was extracted from $1 \mathrm{~g}$ of banana leaf, ground in liquid nitrogen, adding trizol reagent. PCR profile consisted of an initial denaturing step at $94^{\circ} \mathrm{C}$ for 3 min; 35 cycles of $94^{\circ} \mathrm{C}$ for $3 \mathrm{~min}, 1 \mathrm{~min}$ at $60^{\circ} \mathrm{C}$ and $90 \mathrm{~s}$ at $72^{\circ} \mathrm{C}$; with a final extension step at $72^{\circ} \mathrm{C}$ for $10 \mathrm{~min}$.

Rolling-circle amplification (RCA) using the Illustra TempliPhi 100 Amplification Kit (GE Healthcare), was essentially according to the manufacturer's instructions with some modifications as proposed by James et al. (2011). Nucleic acid extract $(1 \mu \mathrm{L})$ was mixed with $5 \mu \mathrm{L}$ of kit sample buffer and $1 \mu \mathrm{L}$ of a $50-\mu \mathrm{M}$ stock solution (each primer at approximately $4.16 \mathrm{pmol} / \mu \mathrm{L}$ ) of degenerate primers $\left(1 \mathrm{~A} / 4^{\prime}\right)$. The mixture was denatured at $95^{\circ} \mathrm{C}$ for 3 min and cooled on ice, and to this was added kit reaction buffer $(5 \mu \mathrm{L})$ premixed with polymerase $(0.2 \mu \mathrm{L})$. The mixtures were incubated at $30^{\circ} \mathrm{C}$ for $18 \mathrm{~h}$ and then the reactions were stopped by incubation at $65^{\circ} \mathrm{C}$ for $10 \mathrm{~min}$. Products of RCA amplification of sample 'Jangada'-13 were independently digested with $K p n I, B a m H I, E c o$ RI, and $X b a \mathrm{I}$ restriction endonucleases and then electrophoresed in $1 \%$ agarose gels in Tris-acetate-EDTA buffer at $100 \mathrm{~V}$ for $75 \mathrm{~min}$. Gels were stained using $0.25 \times$ SYBR Safe DNA Gel Stain (Invitrogen) and visualized on a transilluminator. The approximately $1 \mathrm{Kbp} X b a \mathrm{I}$-digest fragment was excised from gel, purified and ligated into appropriately digested pUC19 plasmid vector which was used to transform cells of Escherichia coli DH5a made competent by heat shock treatment. Plasmid DNA containing inserts were purified and sent for sequencing with universal M13 forward and reverse primers, in a ABI 3730 DNA analyzer (Applied Biosystems), in a lab facility at Universidade de São Paulo.

Products of RT-PCR amplifications with primers (CMV-1/2) were excised from gels, purified and subsequently ligated into the pGem-T Easy Vector (Promega), transformed into competent Escherichia coli DH5 $\alpha$ and sequenced with CMV-1/2 primers following the previously described procedures.Sequences were compared with others from GenBank by the BLAST program of the National Center for Biotechnology Information (NCBI).

Banana producing areas were surveyed through DAS-ELISA with an antiserum for Sugarcane bacilliform virus (SCBV), a badnavirus serologically related to BSV (Lockhart and Autrey, 1988), and BSV was found in single and in mixed infections with CMV (Table 1). DAS-ELISA was as effective as RCA for BSV detection (Table 1), and both tests would be recommended for episomal detection of BSV. However, the efficiency of serological based methods for the episomal detection of BSV has been questioned, considering the uneven BSV distribution within the Musa plant combined with environmental influences, such as high temperatures $\left(28-35^{\circ} \mathrm{C}\right)$ that would cause virus titer to drop below detection levels (Dahal et al., 2000). Additionally, 
TABLE 1 - Comparison of double antibody sandwich (DAS)-ELISA, polymerase chain reaction (PCR) and rolling-circle amplification (RCA) for detection of Banana streak virus (BSV) from Musa, and detection of Cucumber mosaic virus (CMV) by DAS-ELISA.

\begin{tabular}{|c|c|c|c|c|}
\hline Banana leaf samples & $\begin{array}{l}\text { BSV-DAS-ELISA }{ }^{(1)} \\
\quad(405 \mathrm{~nm})^{(2)}\end{array}$ & BSV-PCR ${ }^{(3)}$ & BSV-RCA ${ }^{(3)}$ & $\begin{array}{l}\text { CMV-DAS-ELISA } \\
\qquad\left(405 \mathrm{~nm}^{(2)}\right.\end{array}$ \\
\hline 'Nanicão Jangada'-1 & $\begin{array}{c}- \\
(0,019)\end{array}$ & + & - & $\begin{array}{c}- \\
(0,017)\end{array}$ \\
\hline 'Nanicão Jangada'-4 & $(0,017)$ & + & - & $\begin{array}{c}+ \\
(0,108)\end{array}$ \\
\hline 'Nanicão Jangada'-10 & $\begin{array}{c}+ \\
(0,268)\end{array}$ & + & + & $\begin{array}{c}+ \\
(0,295)\end{array}$ \\
\hline 'Nanicão Jangada'-12 & $\begin{array}{c}+ \\
(0,100)\end{array}$ & + & + & $\begin{array}{c}+ \\
+ \\
(0,042)\end{array}$ \\
\hline 'Nanicão Jangada'-13 & $\begin{array}{c}+ \\
(0,524)\end{array}$ & + & + & $\begin{array}{c}+ \\
(0,225)\end{array}$ \\
\hline 'Prata Anã' & $\begin{array}{c}- \\
(0,016)\end{array}$ & + & - & $(0,013)$ \\
\hline 'Maçã' & $(0,014)$ & + & - & $\begin{array}{c}+ \\
(0,216)\end{array}$ \\
\hline 'Grand Naine' & $(0,007)$ & + & - & $\begin{array}{c}+ \\
(0,218)\end{array}$ \\
\hline 'Nanicão comum' & $\begin{array}{c}- \\
(0,019)\end{array}$ & + & - & $\begin{array}{c}+ \\
(0,061)\end{array}$ \\
\hline 'IAC 2001' & $\begin{array}{c}+ \\
+ \\
(0,052)\end{array}$ & + & - & $(0,016)$ \\
\hline $\begin{array}{l}\text { Banana leaf tissue (Agdia), } \\
\text { negative control }\end{array}$ & $\begin{array}{c}- \\
(0,014)\end{array}$ & $\mathrm{nt}$ & $\mathrm{nt}$ & $\begin{array}{c}- \\
(0,014)\end{array}$ \\
\hline
\end{tabular}

(1) Tested with Sugarcane bacilliform virus antiserum (Agdia), (2) Mean of three absorbance readings at $405 \mathrm{~nm}$, (3) Tested with Badnavirus primers (1A/4') (Harper et al., 2002), (+) positive, (-) negative, (nt) not tested.

the high diversity of BSV would result in serological variability among strains, likely to give false negatives during detection procedures such as ELISA (Ndowora \& Lockhart, 2000).

Likewise, PCR with primers $1 \mathrm{~A} / 4$ ' was successful in BSV detection in symptomatic 'Jangada' samples. However, it could not specifically discriminate infected from not infected plants, considering that many PCR positive samples as 'Prata Ana', 'Maçã', 'Grand Naine' and 'Nanicão comum' were not BSV infected as indicated by ELISA and RCA (Table 1, Figure 1). Several PCR based protocols directly on plant crude extracts or on purified DNA have been used to detect BSV strains, but they have the disadvantage of giving false positives, since PCR primers can detect BSV sequences integrated into the plant genome as episomal virus particles. Moreover, all Musa spp. examined so far, harbor some sequence form of BSV in their DNA (Harper et al., 2002, James et al., 2011).

Results of this study confirmed previous works (James et al., 2011; Wambulwa et al., 2012) that RCA is very reliable to detect episomal $\mathrm{BSV}$, as the sequenceindependent nature of RCA can selectively amplify circular and not linear (integrated) DNA. RCA specifically amplified the genome of episomal BSV present in 'Nanicão Jangada' (Table 1, Figure 2). Subsequent sequence analysis of approximately 1.2-Kbp fragment of $\mathrm{XbaI}$-digestion of RCA product from DNA of 'Nanicão Jangada'-13 revealed 99\% similarity to part of the RT/RNaseH-coding region from
BSOLV. According to ICTV differences within ORF3 of more than $20 \%$ is a demarcation criterion of species in the Badnavirus genus (Geering \& Hull, 2012). Additionally, the RCA polymorphic restriction fragment profile of 1 band obtained by KpnI and BamHI treatment, and the $X b a \mathrm{I}$ profile of 3 bands are in agreement with the predicted for BSOLV, as reported by James et al., (2011), except for EcoRI restriction profile of 3 bands instead of 4 (Figure 2), an indication of a slight nucleotide sequence variability in the examined BSOLV strain.

In this study, detection of CMV and BSV through all tested procedures was sometimes inconsistent (Table 1), probably due to low titer and virus uneven distribution in some banana plants.

RCA has been used for detection of DNA genomes of viruses in the families Geminiviridae, Nanoviridae and Caulimoviridae (Inoue-Nagata et al., 2004; Johne et al., 2009; James et al., 2011). Thus, in the case of BSV, it would be advisable to identify species using RCA amplification of episomal BSV to avoid misidentification by the amplification of virus endogenous sequences.

The episomal BSOLV isolate identified in this work could not come from an integrated form of the virus later expressed causing disease, as 'Nanicão Jangada' belongs to the Cavendish subgroup (AAA), and in A genomes the expression of functional viral transcripts is not found (Geering et al., 2005; James 2011). This emphasizes the 


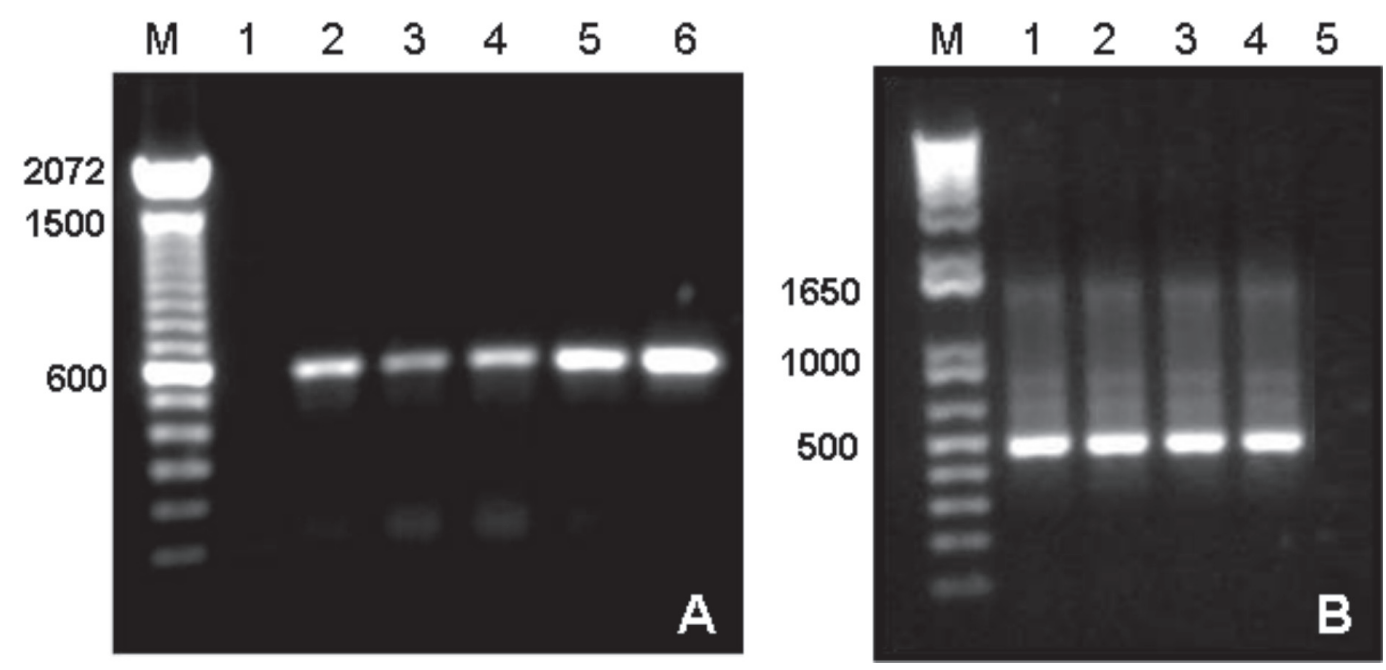

FIGURE 1 - Amplification of nucleic acids from banana leaf extracts. A. PCR with Badnavirus primers 1A/4'. M. 100 bp DNA ladder; 1. Negative control (no DNA); 2. 'Maçã'; 3. 'Grand Naine'; 4. 'Prata Anã'; 5. 'Nanicão Jangada'-10; 6. 'Nanicão Jangada'-13. B. RT-PCR with CMV primers 1/5. M. 1Kbp plus DNA ladder; 1. 'Grand Naine'; 2. 'Maçã'; 3. 'Nanicão Jangada'-10; 4. 'Nanicão Jangada'-13; 5. Healthy 'Nanicão comum'.

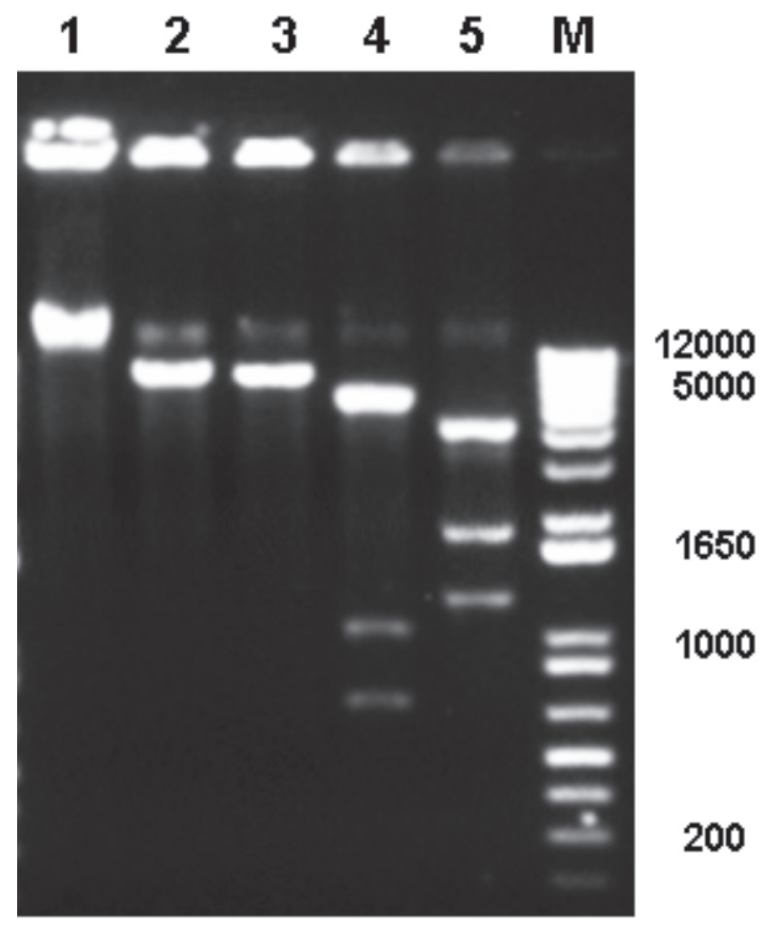

FIGURE 2 - Analysis of rolling-circle amplification (RCA) products with Badnavirus primers $1 \mathrm{~A} / 4$ ' on DNA from leaf extracts of 'Nanicão Jangada'13. M. $1 \mathrm{Kbp}$ plus DNA ladder; 1. RCA product; 2. KpnI-digested, 3. BamHIdigested, 4. EcoRI-digested, 5. XbaIdigested RCA product.

need of indexing banana planting material using the most reliable and sensitive detection tools to avoid the episomal BSV spread through infected planting material.

In Brazil, since the first report of CMV in banana (Ribeiro et al., 1975) there are reports of Musa infection by distinct strains of BSV that are not recognized yet as species in the Badnavirus genus (Brioso et al., 2012, Figueiredo et al., 2006, Poltronieri et al., 2009). Also, there is a report of a PCR detection of a BSOLV isolate from banana 'Terra Ana' (AAB) from São Paulo state (Lombardi at al., 2010).

ELISA and RT-PCR protocols are currently used as standard for CMV indexing of banana. On the other hand, 
RCA-based methods can circumvent most of the drawbacks of these detection tools for banana BSV indexing. Future research should aim to optimize RCA protocols for more time and cost-effective BSV diagnostics.

\section{ACKNOWLEDGMENTS}

This work was supported by FINEP/SEBRAE and Fundação Araucária de Amparo à Pesquisa do Paraná. We also thank Conselho Nacional de Desenvolvimento Científico e Tecnológico - CNPq and Coordenação de Aperfeiçoamento de Pessoal de Nível Superior - CAPES for a fellowship grant.

\section{REFERENCES}

Brioso PST, Cordeiro ZJM, Rezende JAM, Kitajima EW, Pimentel JP, Figueiredo, AR (2000) Infecção mista em bananeiras pelos vírus do mosaico do pepino ("Cucumber mosaic virus" CMV) e da risca da bananeira ("Banana streak virus" BSV) no Brasil. Summa Phytopathologica 26:254-257.

Brioso PST (2012) Badnavirus e seu controle. In: $45^{\circ}$ Congresso Brasileiro de Fitopatologia. Tropical Plant Pathology (Suplemento) 37:1-19.

FAO. Food and Agriculture Organization of the United Nations. Food and Agricultural commodities production, 2012. Available at: http://faostat.fao.org/. Accessed on August 14 ${ }^{\text {th }}, 2013$.

Figueiredo DV, Meissner Filho PE, Silva Neto SP, Brioso PST (2006) Detection and analysis of Banana streak virus (BSV) sequences variability of banana from Brazil. Summa Phytopathologica 32:118-123.

Geering ADW, Olszewski NE, Harper G, Lockhart BEL, Hull R, Thomas, JE (2005) Banana contains a diverse array of endogenous badnaviruses. Journal of General Virology 86:511-520.

Geering ADW, Hull R (2012) Family Caulimoviridae. In: King AMQ, Adams MJ, Carstens EB, Lefkowitz EJ (Eds.) Virus Taxonomy: Ninth Report of the International Committee on Taxonomy of Viruses. San Diego, CA, USA. Academic Press.

Harper G, Hart D, Moult S, Hull R (2002). Detection of Banana streak virus in field samples of bananas from Uganda. Annals of Applied Biology 141:247-257.

Inoue-Nagata AK, Albuquerque LC, Rocha WB, Nagata T (2004) A simple method for cloning the complete begomovirus genome using the bacteriophage phi29 DNA polymerase. Journal of
Virological Methods 116:209-211.

James AP, Geijskes RJ, Dale JL, Harding RM (2011) Development of a novel rolling-circle amplification technique to detect Banana streak virus that also discriminates between integrated and episomal virus sequences. Plant Disease 45:57-62.

Johne R, Müller H, Rector A, van Ranst M, Stevens (2009) Rolling-circle amplification of viral DNA genomes using phi29 polymerase. Trends Microbiology 17:205-211.

Lheureux F, Carreel F, Jenny C, Lockhart BEL, Iskra-Caruana ML (2003) Identification of genetic markers linked to banana streak disease expression in inter-specific Musa hybrids. Theoretical and Applied Genetics 106:594-598.

Lockhart BEL, Autrey JC (1988) Ocurrence in sugarcane of a bacilliform virus related serologically to banana streak virus. Plant Disease 72:230-233.

Lockhart BEL, Jones DR (2000) Banana streak. In: Jones D.R. (Ed.), Diseases of Banana Abaca and Ensete. Wallingford UK. CAB International. pp. 263-274.

Lombardi R, Harakava R, Colariccio A (2010) Clonagem e purificação de fragmento da proteína capsidial de Banana streak OL virus. Pesquisa Agropecuária Brasileira 45:811-817.

Ndowora T, Lockhart BEL (2000) Development of a serological assay detecting serologically diverse Banana streak virus isolates. In: Craenen, K, Ortiz R, Karamura EB, Vuylsteke D (Eds.) Proceedings of the First International Conference on Banana and Plantain for Africa. Acta Horticulture 540:377-388.

Poltronieri LS, Figueiredo DV, Brioso PST, Verzignassi SSC (2009) Constatação do Banana streak Uganda B virus em Bananeiras no Estado do Pará. Summa Phytopathologica 35:74.

Ribeiro MISD, Ribeiro RLD, Maiolino W, Robbs CF (1975) Nota sobre a ocorrência de uma forma severa de mosaico em bananais do Estado do Rio de Janeiro. Revista da Sociedade Brasileira de Fitopatologia 6, 7, 8:26-28.

Simmonds NW (1976) Banana. In: Simmonds NW (Ed.) Evolution of Crop Plants. London, UK. Longman. pp. 211-215.

Wambulwa MC, Francis N, Wachira FN, Karanha LS, Muturi SM (2012) Rolling circle amplification is more sensitive than PCR and serology-based methods in detection of Banana streak virus in Musa germplasm. American Journal of Plant Sciences 3:15811587.

Wylie S, Wilson CR, Jones RAC, Jones MGK (1993) A polymerase chain reaction assay for Cucumber mosaic virus in lupin seeds. Australian Journal of Agriculture Research 44:41-51. 